\title{
Yield Efficiency Evaluation of Double Slope Solar Stills Connected with External Spiral Copper for Potable Water Production
}

\author{
Ebrahim Hamid Hussein Al-Qadami ${ }^{1,5^{*}}$, Amimul Ahsan ${ }^{2,3}$, \\ Abdurrasheed Sa'id Abdurrasheed ${ }^{1,4}$, Zahiraniza Mustaffa', \\ Khamaruzaman Wan Yusof', Husna Takaijudin', Marlinda Abdul Malek ${ }^{6}$ \\ 1 Department of Civil and Environmental Engineering, Universiti Teknologi Petronas, Bandar Seri Iskandar, \\ Perak, Malaysia \\ 2 Department of Civil Engineering, Uttara University, Dhaka, Bangladesh \\ ${ }^{3}$ Department of Civil and Construction Engineering, Swinburne University of Technology, Melbourne, Australia \\ ${ }^{4}$ Department of Civil Engineering, Ahmadu Bello University, Zaria, Nigeria \\ ${ }^{5}$ Department of Civil Engineering, Universiti Putra Malaysia, Serdang, Selangor, Malaysia \\ ${ }^{6}$ Institute of Sustainable Energy (ISE), Universiti Tenaga Nasional, Selangor, 43000, Malaysia \\ * Corresponding author's e-mail: ialgodami@gmail.com
}

\begin{abstract}
Among the key challenges of the $21^{\text {st }}$ century, one can enumerate finding efficient technologies to enhance water purification. Seawater desalination had been identified as one of the main alternative solutions to increase the water resources on our planet and fulfill human demands. In this study, the yield performance of double slope solar still connected with the external spiral copper pipe as the water heater was investigated. Active and passive solar stills of equal evaporation area with covers ( $4 \mathrm{~mm}$ thickness and $45^{\circ}$ slope in both sides) were manufactured using Perspex. Different parameters were investigated and compared during the experiment including yield and water quality indicators from both stills. The results showed a strong relationship between the water production rates and solar radiation intensities, water temperature as well as ambient temperature. Additionally, the water productivity from the active still was $20 \%$ higher compared to the passive one. Overall, the water quality parameters were within the acceptable limits, the rate of distillate water production was found to increase along with solar radiation intensity and water temperature.
\end{abstract}

Keywords: solar still, double slope, active still, passive still, yield estimation, external heater

\section{INTRODUCTION}

Among the key challenges of the 21st century, one can enumerate finding efficient technologies to enhance water purification (Modi and Modi, 2019; Graf, et al, 2010). Research has shown that only $1 \%$ of the Earth's water is fresh and the remaining $99 \%$ are either salty, brackish or frozen (Dev and Tiwari, 2009). As the population grows larger, the amount of water consumption per person per day is increasing faster than the rate of population growth (Kerschner \& Peterson, 2011). Similarly, the World Health Organization (WHO) estimated that by 2025 the worldwide demand for freshwater will exceed the supply by $56 \%$ (Kucera, 2014). Therefore, looking for new solutions and other alternatives to obtain fresh water and increase water resources on our planet becomes increasingly important to fulfill the population demands. With lots of saline water in the seas and oceans, seawater desalination had been identified as one of the main solutions to increase the water resource in our planet, especially by utilizing renewable solar energy sources (Ali, 1993).

The main principle of the desalination process is the separation of salt and fresh water from 
seawater or brackish water and treated wastewater. However, energy demand remains the actual challenge in the technology as t electricity and high-grade thermal energy are required to produce water from dissolved metals. This process releases greenhouse gasses, waste heat and brine (concentrates) to the atmosphere. The daily distillate output of passive solar still can be improved by increasing the temperature difference between the evaporating and condensing surfaces (Tiwari \& Tiwari, 2006). Low productivity is the main disadvantage when compared with other methods of water distillation. In an active solar still, there are many factors affecting the productivity of the still, such as fans, pumps, condensers, and solar collectors. Lots of works on active solar still had been reported by different authors and in terms of increasing productivity using a sun tracking system. An average of $22 \%$ efficiency improvement in the productivity of solar stills was reported by (Abdallah \& Badran, 2008). Similarly, the productivity was doubled by using a storage tank and solar collector. Additionally, in terms of thermal efficiency, the thermal modeling of a double slope active solar still showed that the thermal efficiency of double slope active solar still is lower than that of double slope passive solar still.

Many solar still designs had been improved since their benefits have been recognized. They have several advantages when compared with other desalination technologies such as thermal methods including multi-stage flash (MSF), multi-effect desalination (MED), and electro diaysis (ED) or membrane technologies including reverse osmosis (RO), ultra-filtration (UF), and nano-filtration (NF), which use a lot of energy. Solar desalination uses solar power which is available throughout the year and has no effect on the environment. Additionally, the simplicity of construction and ease of maintenance are among the key advantages of solar still technology. There are various designs of solar stills including single basin, film covered, wick, spherical, pyramidal, hemispherical, tubular, and double-basin solar stills (Al-sulttani et al, 2017). The general performance of solar stills depends on three main factors, namely ambient, design, and operating conditions. The ambient conditions include solar radiation, ambient temperature, isolation, and wind velocity (Aburideh et al., 2012; Tiwari \& Tiwari, 2006; Muftah et al., 2014). A number of studies were carried out to study the performance variations and productivity based on the effects of climatic parameters (Al-Hinai et al., 2002). A simultaneous increase in productivity was reported in the solar still with an increase in temperature (Muftah et al., 2014). Similarly, solar still productivity was found to increase with the temperature difference between the condensate cover and the basin (Xiao et al., 2013; Dai, 2011). This paper, therefore, investigates the yield efficiency of both active and passive double slope solar stills connected with external spiral copper water pipe heater for potable water production.

\section{METHODOLOGY}

\section{Solar Still Fabrication Procedure}

In this study, for the purpose of the field experiment, two types of double slope solar still were designed and constructed to study the performance of active solar still connected with a copper pipe which works as external water solar heater. Both stills were fabricated with locally available, inexpensive and lightweight materials for practical use. The active still consists of the trough, double slope cover, copper pipe, pump, and storage tank. The passive one consists of the trough and a double slope cover. All parts of these models were made of Perspex with a size of $4 \mathrm{~mm}$, external heater made of spiral copper pipe painted black and placed inside a closed box made of Perspex. Figure 1 shows the fabrication steps of solar stills.

In addiiton, evaporation and condensation processes took place in the same still. A $90 \times 20 \times 5 \mathrm{~cm}$ black painted trough was made from $4 \mathrm{~mm}$ Perspex sheet to hold the saline water samples. The top cover of the still was from $4 \mathrm{~mm}$ Perspex with the dimensions of $105 \times 26 \mathrm{~cm}$ and inclined angle of $45^{\circ}$. The total height of the solar still is $18.8 \mathrm{~cm}$. External water heater system was made of $9.52 \mathrm{~mm}$ diameter copper tube and 15 meters in length. The copper tube was painted with a black color to absorb more solar radiation. The tube pipe was designed to be inside a closed box which was made of Perspex and was painted with black from all sides except the top cover, as shown in Figure 2. The water pump was installed to enhance the water cycling between the trough and an external heater. 


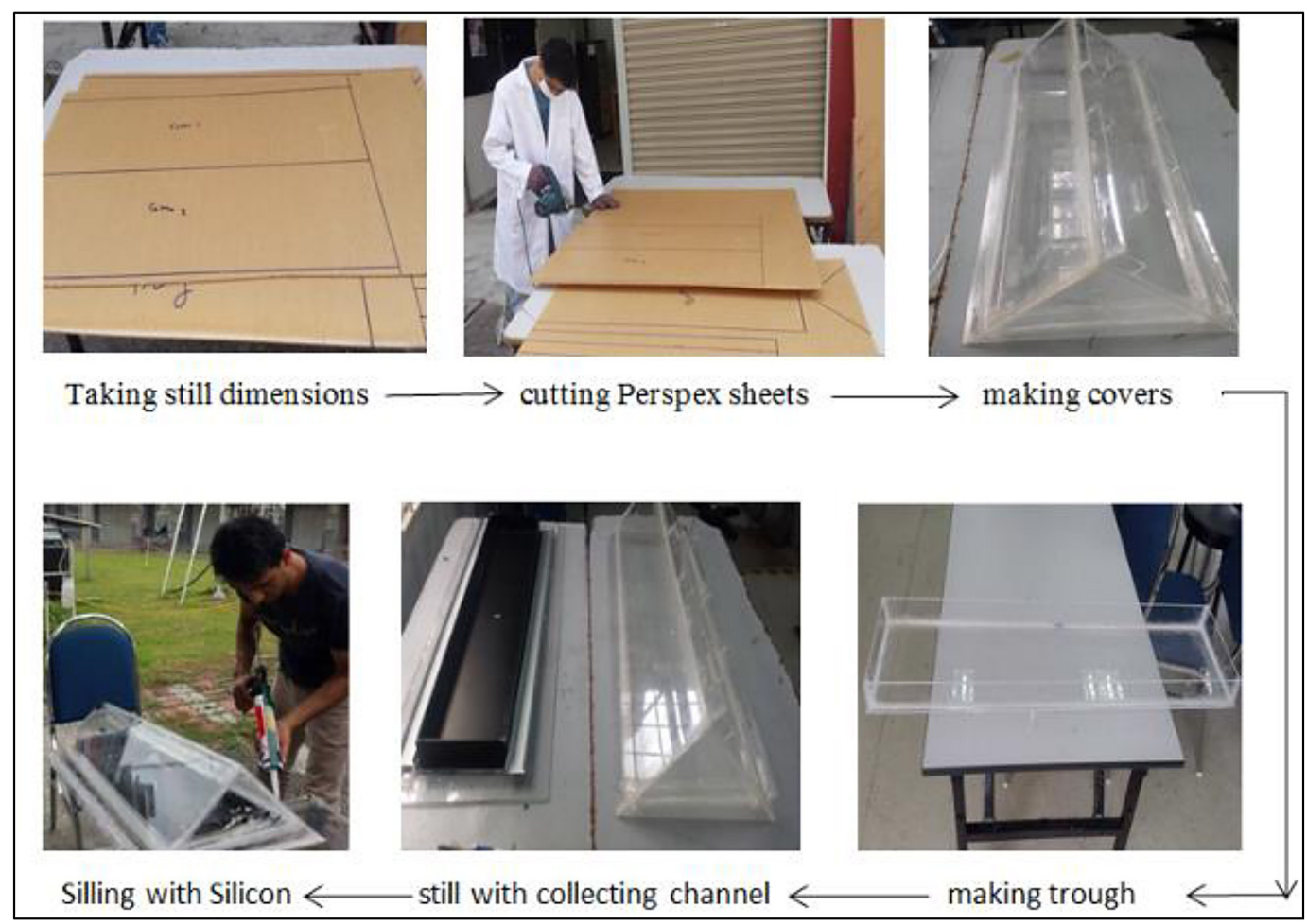

Figure 1. Solar still fabrication process

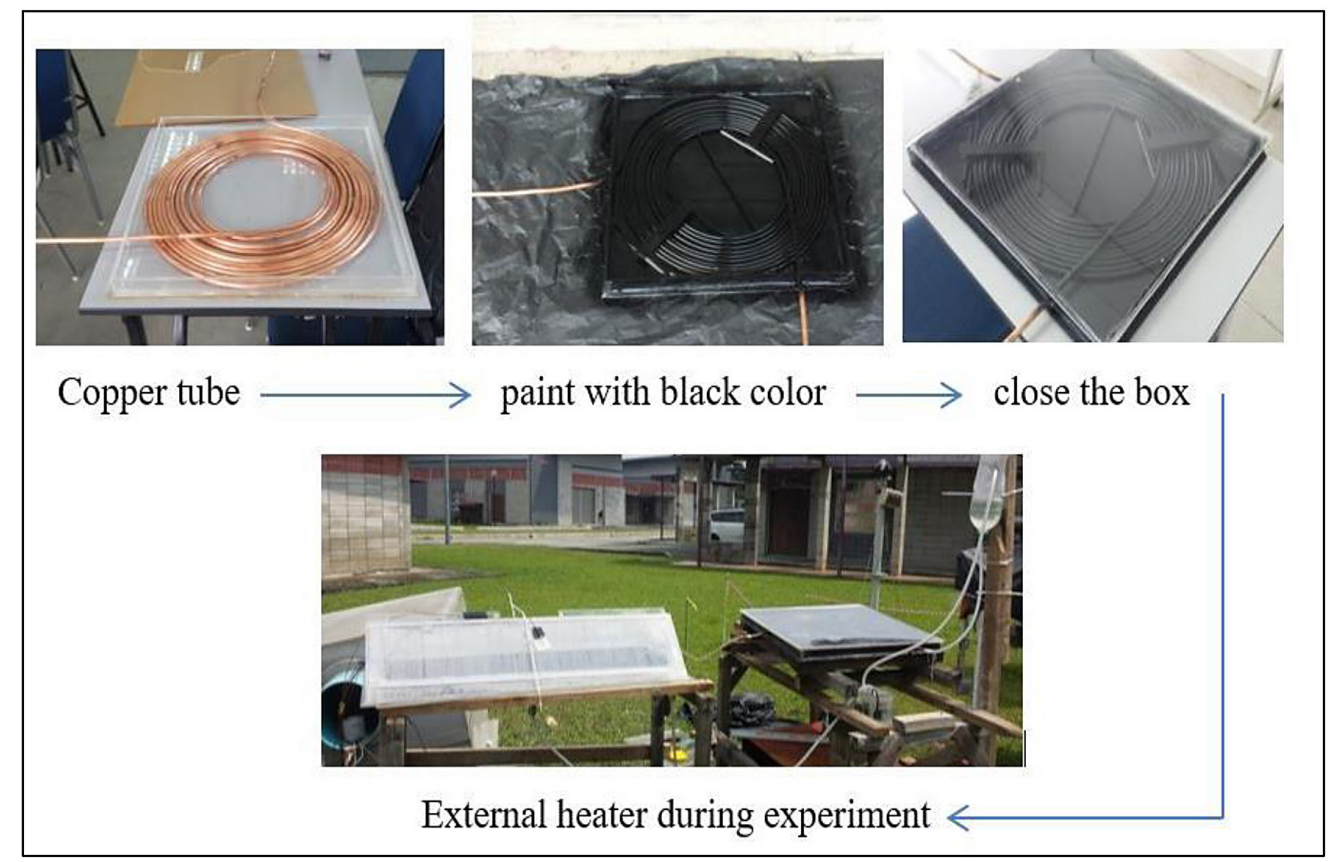

Figure 2. Spiral copper pipe external heater

\section{Experimental setup procedure}

In the morning, the process starts by filling both active and passive stills with $1 \mathrm{~cm}$ depth $\left(1800 \mathrm{~cm}^{3}\right)$ of seawater which is equivalent to $1 \mathrm{~cm}$ depth inside the trough. External tube heater was also filled with $900 \mathrm{~cm}^{3}$ and $0.5 \mathrm{~cm}$ depth inside the trough. For the active still, the first cycle started after half an hour. About $900 \mathrm{~cm}^{3}$ of water was pumped from the trough into the storage tank. At the same time, the seawater inside the external heater flows into the trough. The temperature of the seawater inside the external copper tube heater was observed to be higher than the seawater temperature inside the trough and therefore, the seawater temperature inside the trough 
Table 1. Properties of material used for the solar stills

\begin{tabular}{|c|l|c|c|}
\hline Parts & \multicolumn{1}{|c|}{ Items } & $\begin{array}{c}\text { Passive } \\
\text { solar still }\end{array}$ & $\begin{array}{c}\text { Active } \\
\text { solar still }\end{array}$ \\
\hline \multirow{3}{*}{$\begin{array}{c}\text { Cover } \\
\text { and } \\
\text { trough }\end{array}$} & Cover material & Perspex sheet & Perspex sheet \\
\cline { 2 - 4 } & Thickness $(\mathrm{mm})$ & 4 & 4 \\
\cline { 2 - 4 } & Transmissivity $(\%)$ & 92 & 92 \\
\cline { 2 - 4 } & Density $\left(\mathrm{g} / \mathrm{cm}^{3}\right)$ & 1.190 & 1.190 \\
\cline { 2 - 4 } & Melting point $\left({ }^{\circ} \mathrm{C}\right)$ & 160 & 160 \\
\hline
\end{tabular}

Table 2. Specification of solar stills

\begin{tabular}{|c|l|c|c|}
\hline Parts & \multicolumn{1}{|c|}{ Items } & $\begin{array}{c}\text { Passive } \\
\text { solar still }\end{array}$ & $\begin{array}{c}\text { Active } \\
\text { solar still }\end{array}$ \\
\hline \multirow{5}{*}{ Cover } & Cover shape & Triangular & Triangular \\
\cline { 2 - 4 } & Cover length $(\mathrm{m})$ & 1.05 & 1.05 \\
\cline { 2 - 4 } & Cover width $(\mathrm{m})$ & 0.26 & 0.26 \\
\cline { 2 - 5 } & Cover hight $(\mathrm{m})$ & 0.188 & 0.188 \\
\cline { 2 - 5 } & Inclination angle $\left(^{\circ}\right)$ & 45 & 45 \\
\hline \multirow{4}{*}{ Trough } & Trough shape & Rectangular & Rectangular \\
\cline { 2 - 5 } & Trough length $(\mathrm{m})$ & 0.90 & 0.90 \\
\cline { 2 - 5 } & Trough width $(\mathrm{m})$ & 0.20 & 0.20 \\
\cline { 2 - 5 } & Trough hight $(\mathrm{m})$ & 0.05 & 0.05 \\
\hline
\end{tabular}

of the action still was higher than the one inside the passive still. This cycle works continuously for the whole day.

Figure 3 shows the active and passive solar still at the field during the experiment. Freshwater was collected and weighed each hour for the whole day (sunrise-sunset) to measure the productivity of stills. Similarly, thermocouple wires were placed inside the stills, external heater and connected to the data logger to measure the temperatures per minute. The thermocouples were placed in different locations including the trough side, water, within the cover, outside of the cover for both stills. One thermocouple was placed outside to measure the ambient temperature. The solar radiation meter was also connected to the data logger to measure different solar radiation during the experiment. Relative humidity sensors were placed in both the active and passive solar stills to measure the percentage of humid air inside the

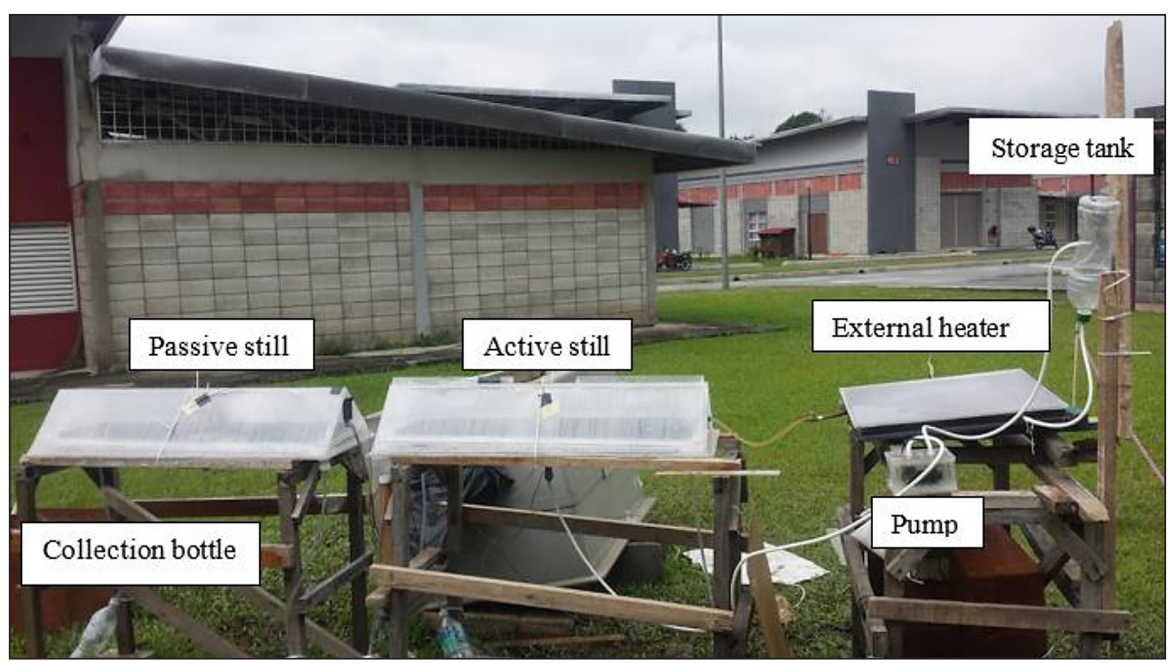

Figure 3. Active and passive solar still in the field

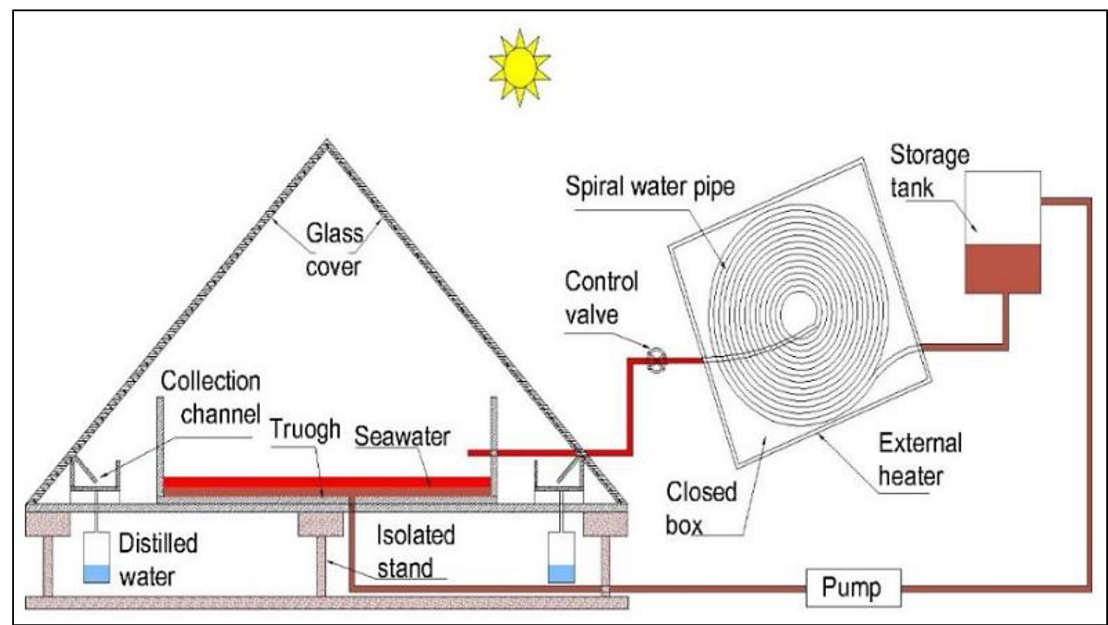

Figure 4. Schematic diagram of the solar still 
stills. All experiments were conducted at the Faculty of Engineering of Universiti Putra Malaysia (UPM). The seawater samples were collected from the Port Dickson (PD) coast. Additionally, water quality parameters such as $\mathrm{pH}$, Total Suspended Solids (TSS), Salinity, Total Dissolved Solids (TDS), electrical conductivity (EC) and turbidity were tested and analyzed before and after the distillation process.

\section{Properties and specifications of solar still used}

Table 1 and 2 show the properties of the materials used during the fabrication of the active and passive solar stills. A clear schematic diagram of the solar still is also presented in Figure 4.

\section{RESULTS AND DISCUSSION}

\section{Variation of hourly production and solar radiation}

On the basis of the field experiment results, the distilled water productivity from both solar stills (active and passive) was directly proportional to the solar radiation intensity, as shown in Figures 5-9. The results can be explained by the main concept of evaporation and condensation process. When the solar radiation

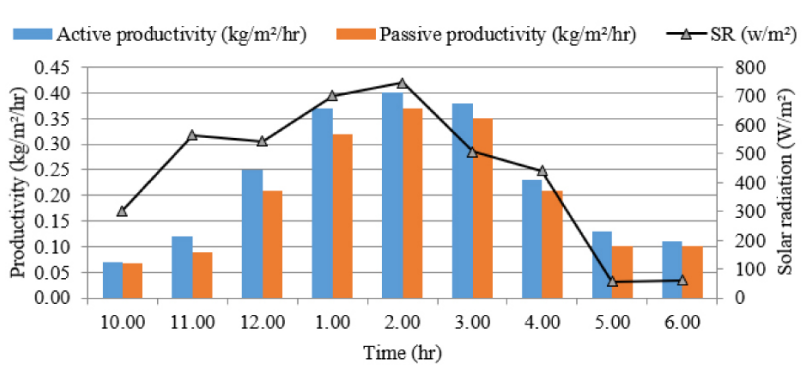

Figure 5. Variation of hourly production and solar radiation on $30^{\text {th }}$ April

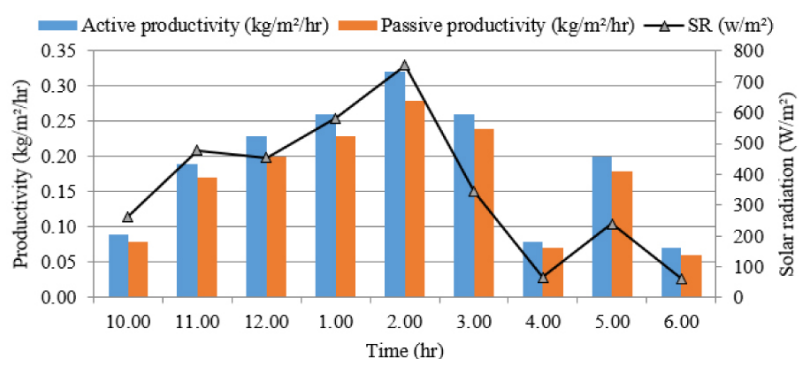

Figure 7. Variation of hourly production and solar radiation on $2^{\text {nd }}$ May increases, it heats up the water inside the solar still leading to an increase in the evaporation rate, which eventually results in a higher water production rate. Figure 5 shows the results of $30^{\text {th }}$ April it can be observed that solar radiation increased gradually from 9 am until reaching its peak at about $2 \mathrm{pm}$. On this day, the minimum solar radiation intensity recorded was $57.12 \mathrm{w} / \mathrm{m}^{2}$ at $5 \mathrm{pm}$ due to the very cloudy sky and a maximum of $746.98 \mathrm{w} / \mathrm{m}^{2}$ at $2 \mathrm{pm}$ where the sky was clear.

Morover, active and passive solar stills hourly production on this same day increased consistently with the increase in solar radiation, reaching the maximum production rate at $2 \mathrm{pm}$, which was $0.40 \mathrm{~kg} / \mathrm{m}^{2} / \mathrm{hr}$ due to the high evaporation rate. However, after $2 \mathrm{pm}$, following a decrease in temperature of water in the trough, the solar radiation decreased continuously causing a simultaneous decrease in water production. Similar trends can be observed in Figures 6 and Figures 7-9 with maximum solar radiations of $747.88,753.28,587.80$, and $795.62 \mathrm{w} / \mathrm{m}^{2}$, respectively. The hourly water production in both stills on the 6 days were $0.41,0.34,0.32,0.28$, $0.35,0.30$ and $0.38,0.35 \mathrm{a} \mathrm{kg} / \mathrm{m}^{2}$, respectively, with a maximum on the $1^{\text {st }}$ of May due to high solar intensity. These results support the findings by (Nafey et al., 2000; Muftah et al., 2014) and (Aburideh et al., 2012).

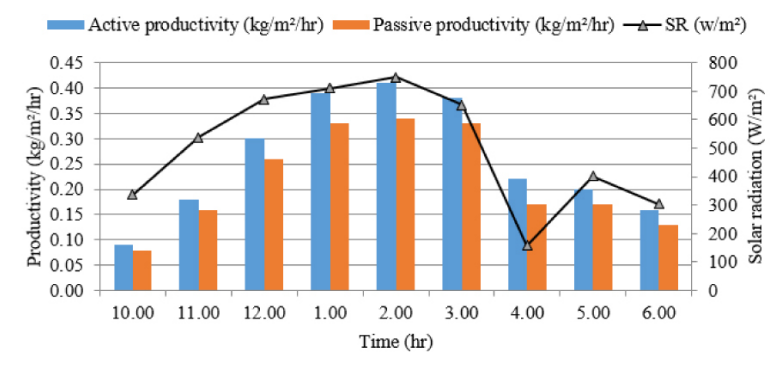

Figure 6. Variation of hourly production and solar radiation on 1st May

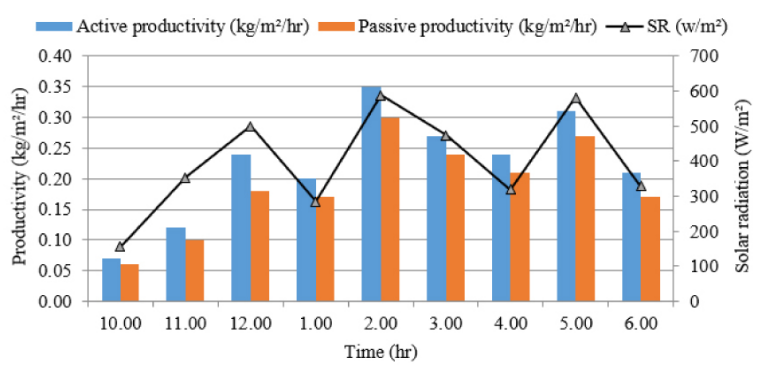

Figure 8. Variation of hourly production and solar radiation on $3^{\text {rd }}$ May 


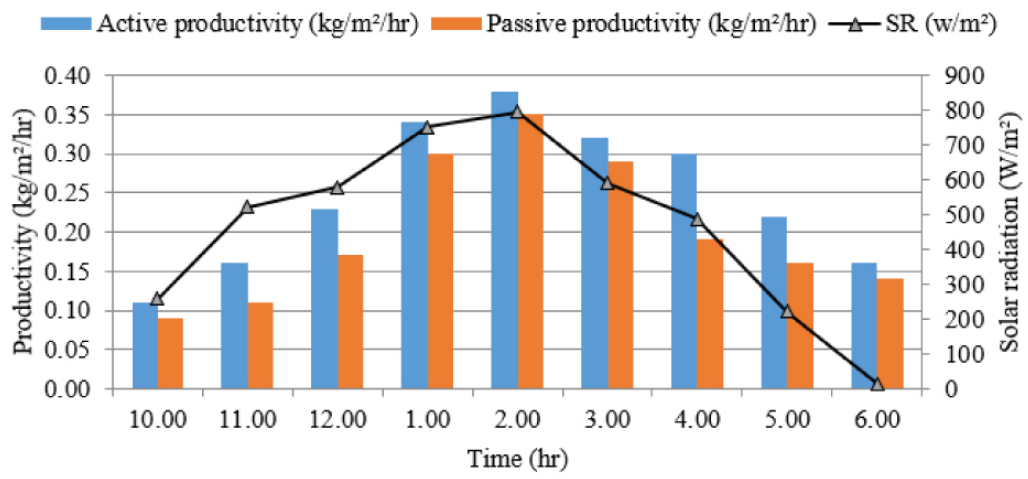

Figure 9. Variation of hourly production and solar radiation on $4^{\text {th }}$ May

\section{Variation of hourly production with ambient temperature and relative humidity}

Figures 10-14 show the relationship between relative humidity, ambient temperature, and production rates of solar stills. It can be observed that the relative humidity increases along with solar radiation and ambient temperature as the amount of vapor inside the solar still also increases with solar radiation. Similarly, when the relative humidity grows the water production rate increases as well. This observation agrees with the work of (Al-Hinai et al., 2002) and (Muftah et al., 2014). On the $30^{\text {th }}$ April, the relative humidity of both

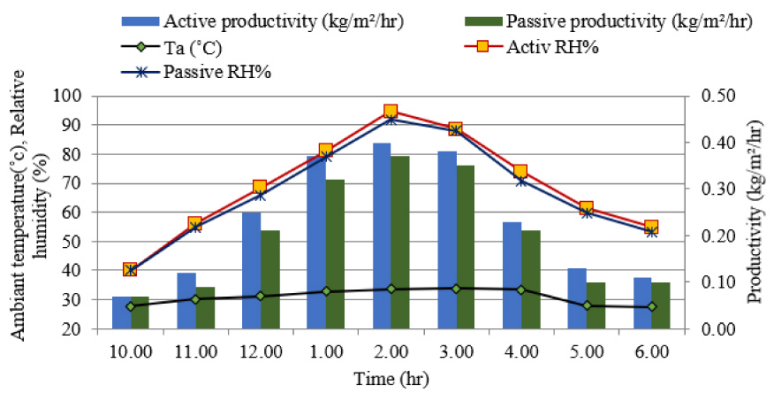

Figure 10. Variation of hourly production, ambient temperature and relative humidity of humid air for active and passive stills on $30^{\text {th }}$ April

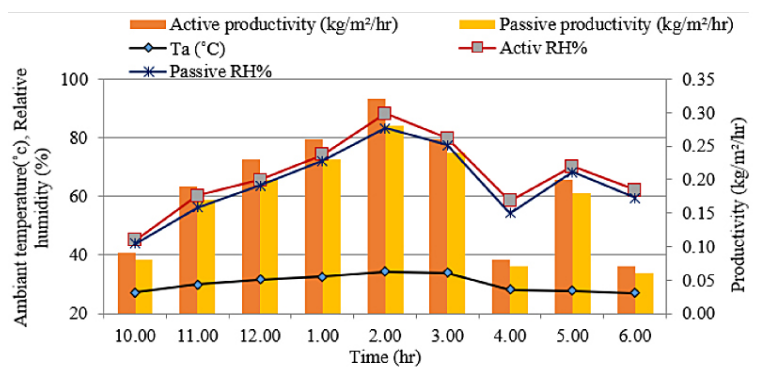

Figure 12. Variation of hourly production, ambient temperature and relative humidity of humid air for active and passive stills on $2^{\text {nd }}$ May the active and passive stills were $40.1 \%$ and $40 \%$, respectively. The relative humidity had a simple value in the morning, as there was little vapor inside the solar still and the ambient air inside was not humid. However, the relative humidity of both stills was later seen to increase along with solar radiation, reaching a maximum value at 2 pm with maximum solar radiation. Subsequently, after $2 \mathrm{pm}$, the solar radiation decreased simultaneously with the relative humidity. From the graphs, it can be clearly inferred that an increase in relative humidity will result in a subsequent increase in the freshwater production.

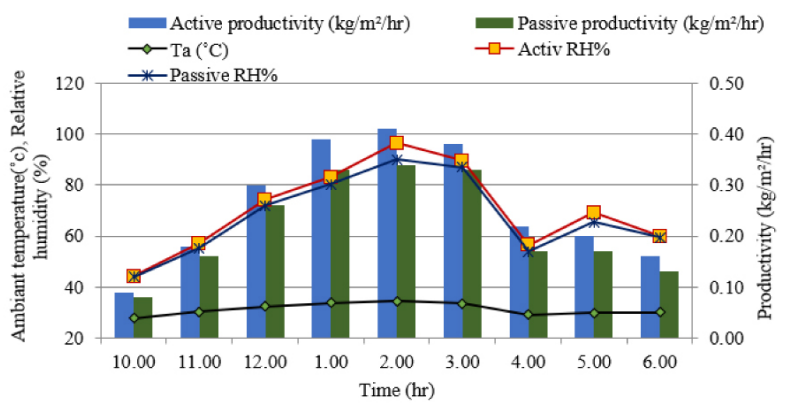

Figure 11. Variation of hourly production, ambient temperature and relative humidity of humid air for active and passive stills on $1^{\text {st }}$ May

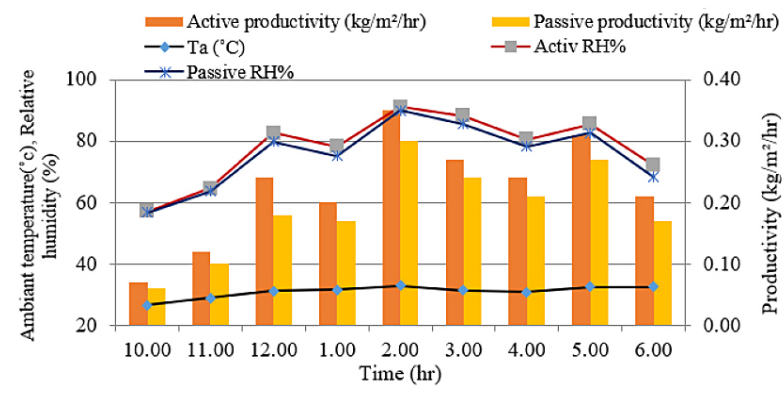

Figure 13. Variation of hourly production, ambient temperature and relative humidity of humid air for active and passive stills on $3^{\text {rd }}$ May 


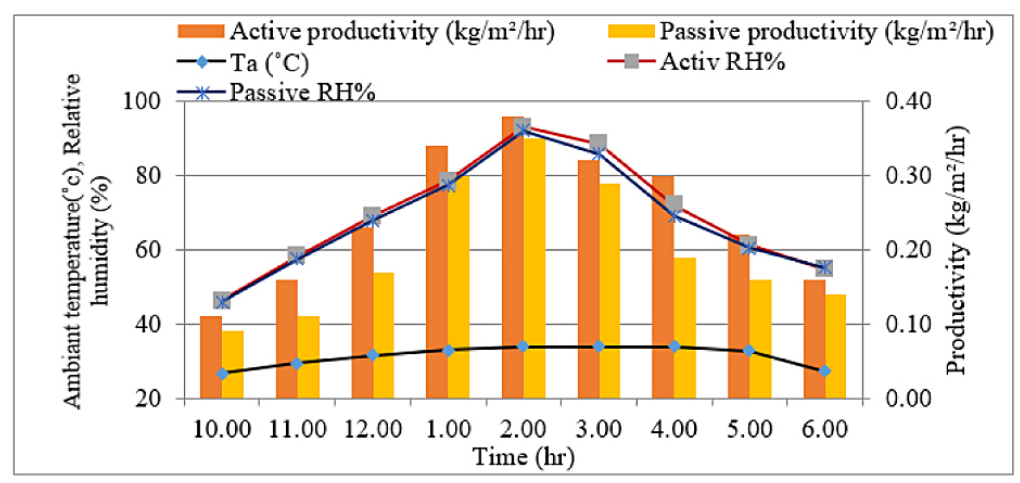

Figure 14. Variation of hourly production, ambient temperature and relative humidity of humid air for active and passive stills on $4^{\text {th }}$ May

\section{Variation of solar radiation, water temperature, trough temperature, and cover material temperature}

The difference between water temperature, internal cover face temperature, and outer cover temperature are among the main parameters that strongly affect the water production in solar stills.

When the water vapor temperature increases and the external cover face temperature decreases, the water condensation will increase, resulting in the production of a greater amount of distilled water. The relationship between trough temperature (Tt), water sample temperature $(\mathrm{Tw})$, temperature of the internal and external face of the solar stills

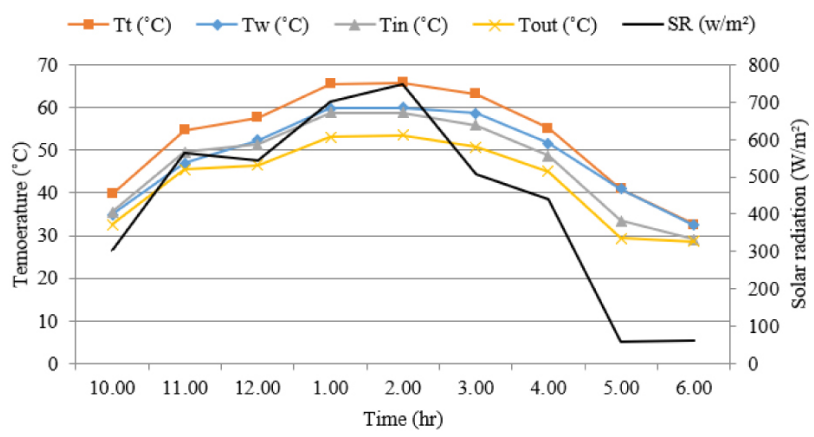

Figure 15. Variation of Tt, Tw, Tin, Tout, and SR for active still on $30^{\text {th }}$ April

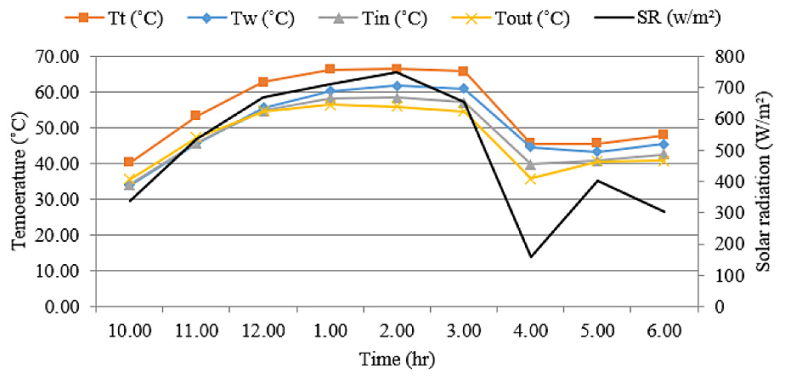

Figure 17. Variation of Tt, Tw, Tin, Tout, and SR for active still on $1^{\text {st }}$ May cover material (Tic) and (Toc), respectively, and solar radiation intensity (SR) can be seen in Figures 15-24. It can be clearly observed that the Tt, Tw, Tic, and Toc are directly proportional to solar radiation intensity. The amount of distilled water produced increases with an increase in Tt, Tw, and Tic.

On $30^{\text {th }}$ April, the maximum trough temperature for active and passive stills recorded were 65.92 and $63.85^{\circ} \mathrm{C}$ respectively at $2 \mathrm{pm}$. Similarly, on $1^{\text {st }}, 2^{\text {nd }}, 3^{\text {rd }}$ and $4^{\text {th }}$, the highest temperature of trough material was recorded at $2 \mathrm{pm}$ for both active and passive solar stills. As shown in Figures 15-24, in the first two hours, the temperature of the external cover face was greater than the water sample temperature because the

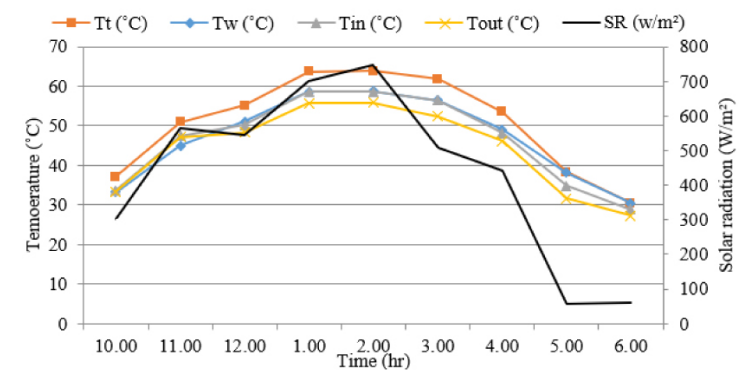

Figure 16. Variation of Tt, Tw, Tin, Tout, and SR fo passive still on $30^{\text {th }}$ April

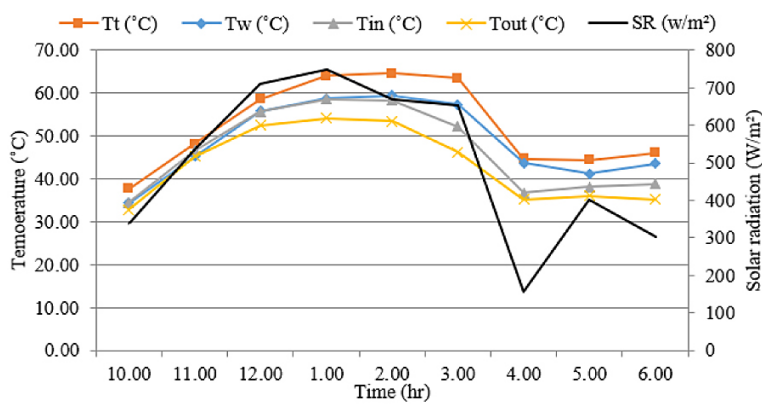

Figure 18. Variation of Tt, Tw, Tin, Tout, and SR for passive still on $1^{\text {st }}$ May 


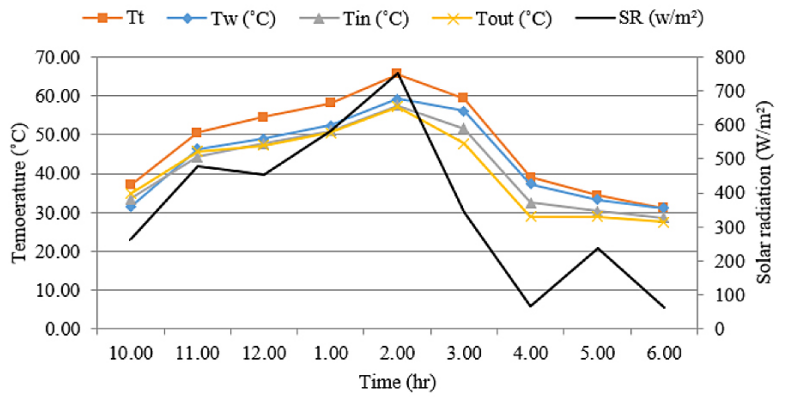

Figure 19. Variation of Tt, Tw, Tin, Tout, and SR for active still on $2^{\text {nd }}$ May

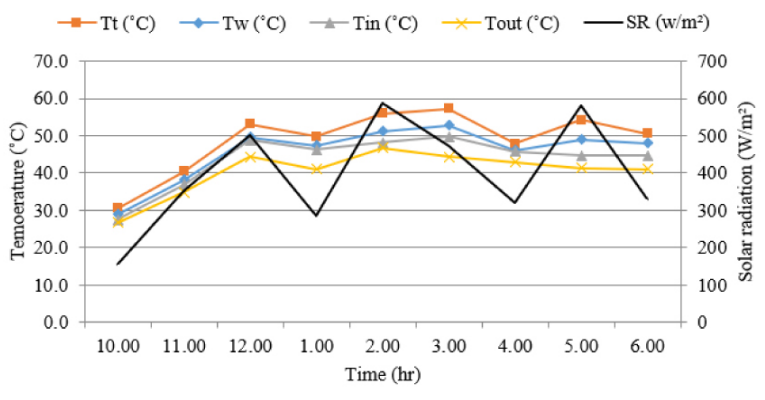

Figure 21. Variation of Tt, Tw, Tin, Tout, and SR for active still on $3^{\text {rd }}$ May

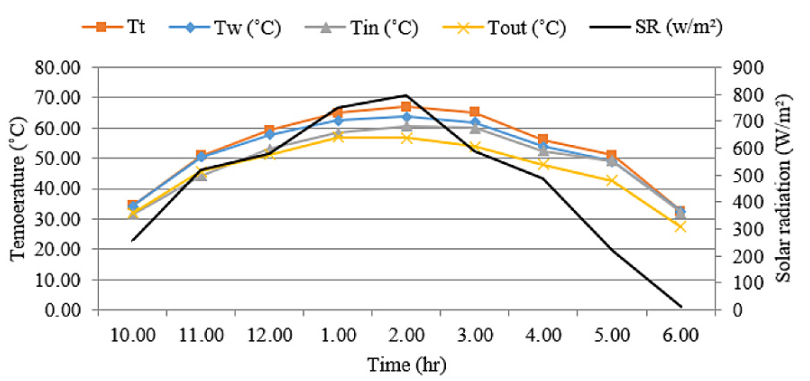

Figure 23. Variation of Tt, Tw, Tin, Tout, and SR for active still on $4^{\text {th }}$ May

cover material absorbs the solar radiation faster than the water which later became hotter for the rest of the day.

\section{Cumulative daily solar radiation and daily water production}

Figure 25 shows the linear equation and represents the relationship between the daily solar radiation intensity and daily distilled water production for active and passive solar stills throughout the five days tested with very good R-square values. The regression line gives an estimation of the true relationship between the total daily production and total daily solar radiation.

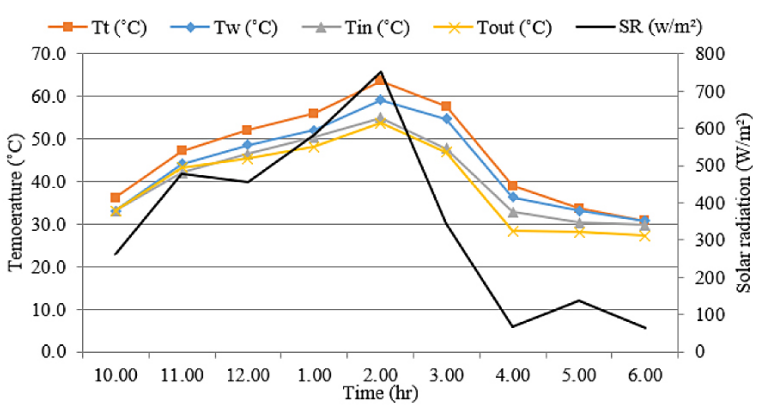

Figure 20. Variation of Tt, Tw, Tin, Tout, and SR for passive still on $2^{\text {nd }}$ May

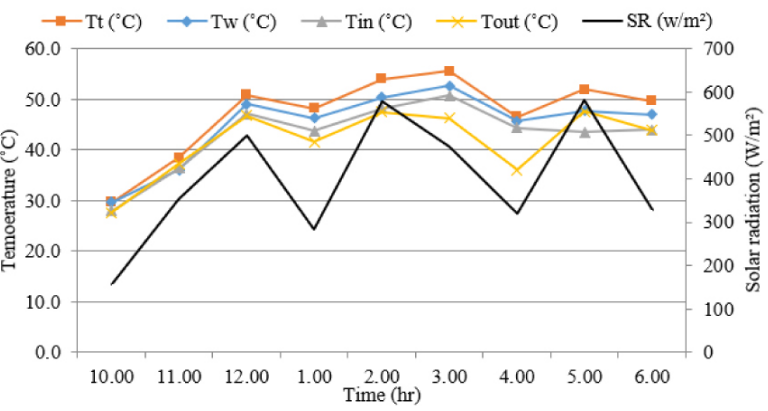

Figure 22. Variation of Tt, Tw, Tin, Tout, and SR for passive still on $3^{\text {rd }}$ May

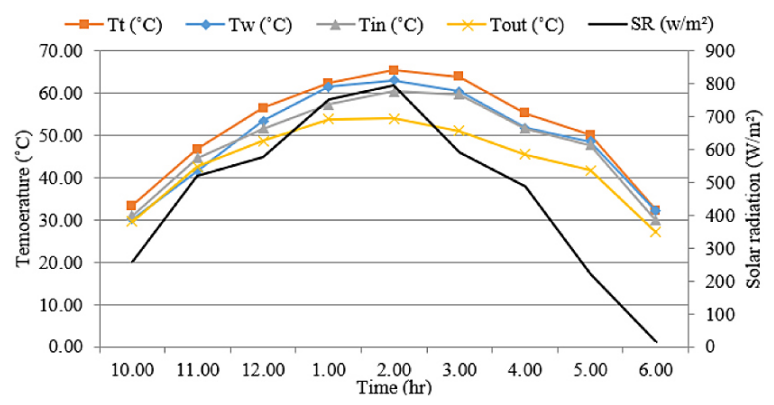

Figure 24. Variation of Tt, Tw, Tin, Tout, and SR for passive still on $4^{\text {th }}$ May

The linear behavior of the linear equation at the coefficient of correlation $\mathrm{R}^{2}=0.9619$ for active still and $\mathrm{R}^{2}=0.9299$ for passive still, showed that there is a strong relationship between daily production and solar radiation.

\section{The relation between daily water production and average daily ambient temperature}

The linear relationship between solar still daily water productivity and the average daily ambient temperature is shown in Figure 26. The $\mathrm{R}$-square coefficient of active and passive solar stills are $\mathrm{R}^{2}=0.9699$ and $\mathrm{R}^{2}=0.8046$, respectively, which confirmed a strong relationship 


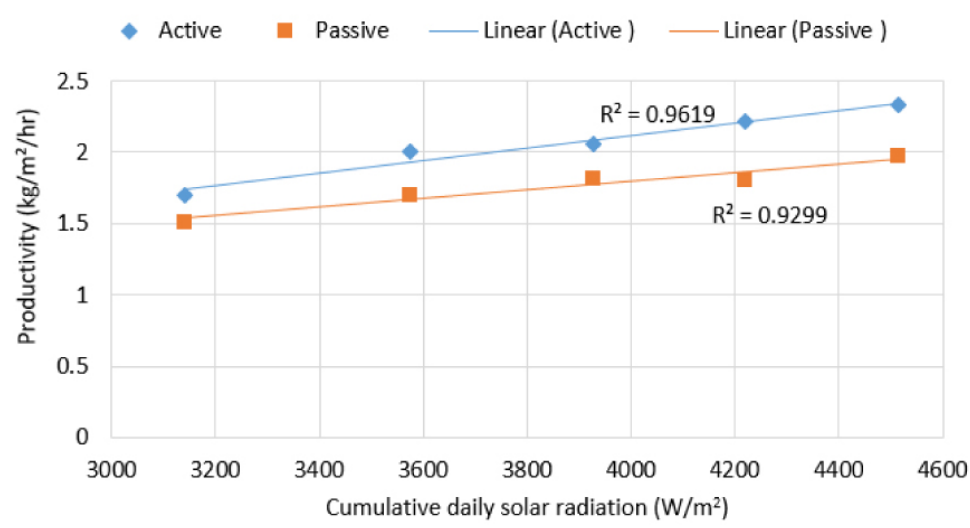

Figure 25. Relationship between daily solar radiation intensity and daily distilled water production

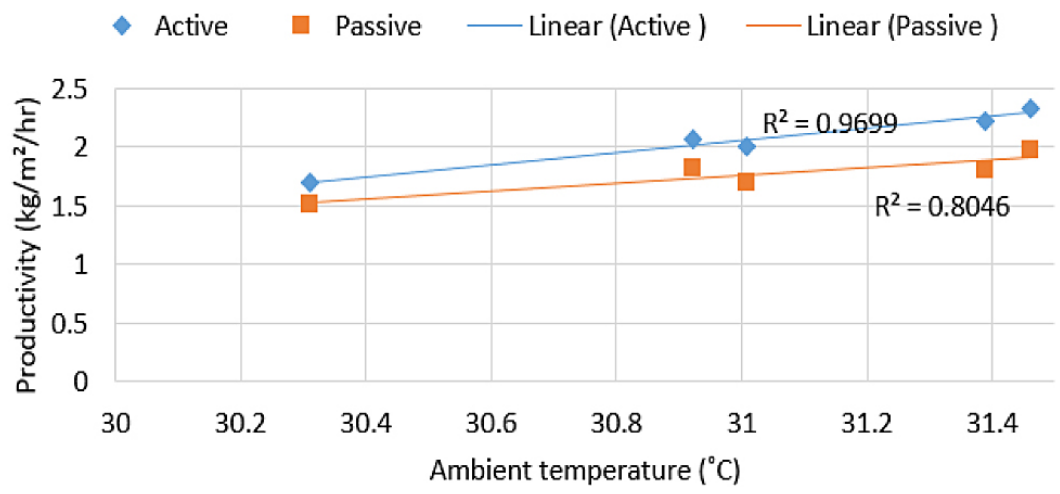

Figure 26. Relationship between daily distilled water production and daily average ambient temperature

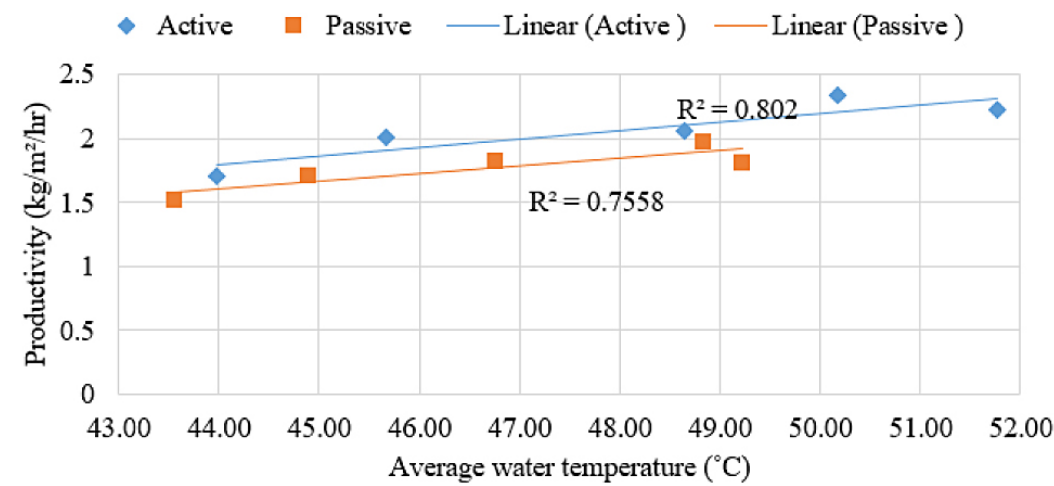

Figure 27. Relationship between daily distilled water production and daily average seawater temperature

between the solar still productivity and ambient temperature.

\section{The relation between daily water production and average daily water temperature}

Figure 27 shows the relationship between stills productivity and the average daily temperature of the seawater inside the trough. The $\mathrm{R}$-square coefficients for active and passive still are $\mathrm{R}^{2}=0.802$ and $\mathrm{R}^{2}=0.7558$, which are close to one. These coefficients showed the strong relationship between distilled water production rates and seawater temperatures inside the trough.

\section{Water quality parameters analysis}

Table 3 shows water quality parameters for seawater (raw) and product water samples tested for both the active and passive solar stills. In accordance to the water quality standards for Malaysia, water with values of EC, salinity and TDS less than $2500 \mu \mathrm{S} / \mathrm{cm}, 200 \mathrm{ppm}$ and $1000 \mathrm{mg} / \mathrm{l}$, respectively, are considered safe and acceptable for drinking purposes. For $\mathrm{pH}$, the values 
Table 3. Water quality parameters

\begin{tabular}{|c|c|c|c|c|c|}
\hline \multirow{2}{*}{ Parameter } & \multirow{2}{*}{$\begin{array}{c}\text { Water quality standards } \\
\text { for Malaysia }\end{array}$} & \multicolumn{3}{|c|}{ Water sample } & $\begin{array}{c}\text { Removal efficiency (active } \\
\text { solar still) }(\%)\end{array}$ \\
\cline { 3 - 5 } & 10 & 12.5 & 9.32 & 9.09 & 25.4 \\
\hline COD $(\mathrm{mg} / \mathrm{l})$ & 3 & 3 & 2.58 & 2.64 & 14.0 \\
\hline BOD $(\mathrm{mg} / \mathrm{l})$ & 500 & 32405 & 180.16 & 181.07 & 99.4 \\
\hline TDS $(\mathrm{mg} / \mathrm{l})$ & 25 & 554 & 20 & 20 & 96.3 \\
\hline TSS $(\mathrm{mg} / \mathrm{l})$ & 200 & 12300 & 100 & 100 & 99.2 \\
\hline Salinity $(\mathrm{ppm})$ & 5 & 6.82 & 0.234 & 0.235 & 96.5 \\
\hline Turbidity $(\mathrm{NTU})$ & 500 & 22780 & 59.63 & 59.57 & 99.8 \\
\hline EC $(\mu \mathrm{s} / \mathrm{cm})$ & $6.5-8.5$ & 7.75 & 7.211 & 7.197 & 6.65 \\
\hline pH & 0 & 28 & 0 & 0 & 100 \\
\hline $\begin{array}{c}\text { Total coliform } \\
\text { (CFU/100ml) }\end{array}$ & & & & & \\
\hline
\end{tabular}

need to be in the range of 6.5 to 8.5 for water to be considered acceptable for drinking. From the experimental results, it can be observed that the TDS, TSS, and salinity were reduced by a percentage of $99.4 \%, 92.8 \%$, and $99.2 \%$, respectively. That is because all metals and salts settled down to the bed of the trough during the evaporation process. In addition, the (COD) and (BOD) values were reduced from 12.5 and 3 to 9.32 and 2.52, respectively. This reduction was due to the evaporation process leaving all biodegradable and biochemical materials in the trough. These results support the findings of an earlier study by Kabeel et al., (2016).

\section{CONCLUSIONS}

In this study, two solar stills were fabricated and tested experimentally to assess and compare their yield efficiencies in potable water production. From the experiments conducted, the following conclusions can be drawn:

1. The maximum production rate from active solar still was $2.33 \mathrm{~kg} / \mathrm{m}^{2}$ on the $1^{\text {st }}$ of May. The productivity of active solar still on $30^{\text {th }}$ of April $2^{\text {nd }}, 3^{\text {rd }}$, and $4^{\text {th }}$, of May, were $2.06,1.70,2.01$, and $2.22 \mathrm{~kg} / \mathrm{m}^{2}$, respectively.

2. Moreover, it was observed that the production of water by active solar still increased by $20 \%$ compared to the productivity of the passive solar still. This was because the sun heated the external heater leading to an increase in the water temperature outside the still before it went to the trough.

3. Similarly, a strong relationship was observed between the water production rates and solar radiation intensity with $\mathrm{R}^{2}$ values of 0.96 and 0.93 for both active and passive solar stills, respectively. A similar relationship was found in the case of water productivity, water temperature and ambient temperature.

4. In terms of water quality conducted before and after the experiments, all values of the tested parameters fell between the ranges for drinking water guideline, provided by the national water quality standards of Malaysia.

5. The study also recommended further research on the effectiveness of the solar still on the removal of heavy metals such as arsenic and lead as well as the possibility of extending the external copper tube heater in the design to contain more water.

\section{Acknowledgements}

The authors wish to acknowledge the Universiti Putra Malaysia (UPM) for providing the enabling environment to conduct this research and iRMC Bold2025, Universiti Tenaga Nasional, Malaysia. Grant Code: RJO 10436494.

\section{REFERENCES}

1. Abdallah, S., Badran, O.O. 2008. Sun tracking system for productivity enhancement of solar still. Desalination, 220(1), 669-676.

2. Aburideh, H., Deliou, A., Abbad, B., Alaoui, F., Tassalit, D., Tigrine, Z. 2012. An experimental study of a solar still: Application on the sea water desalination of Fouka. Procedia Engineering, 33, 475-484

3. Al-Hinai, H., Al-Nassri, M.S., Jubran, B.A. 2002. Effect of climatic, design and operational param- 
eters on the yield of a simple solar still. Energy Conversion and Management, 43(13), 1639-1650.

4. Ali, H.M. 1993. Effect of forced convection inside the solar still on heat and mass transfer coefficients. Energy Conversion and Management, 34(1), 73-79.

5. Dai, A. 2011. Drought under global warming: a review. Wiley Interdisciplinary Reviews: Climate Change, 2(1), 45-65.

6. Dev, R., Tiwari, G.N. 2009. Characteristic equation of a passive solar still. Desalination, 245(1), 246-265.

7. Graf, J., Togouet, S.Z., Kemka, N., Niyitegeka, D., Meierhofer, R., Pieboji, J.G. 2010. Health gains from solar water disinfection (SODIS): evaluation of a water quality intervention in Yaounde, Cameroon. Journal of Water and Health, 8(4), 779-796.

8. Kabeel, A.E., Omara, Z. M., Essa, F.A., Abdullah, A.S. 2016. Solar still with condenser-A detailed review. Renewable and Sustainable Energy Reviews, 59, 839-857.

9. Kerschner, E.M., Peterson, M.W. 2011. Peak Water: The Preeminent 21st Century Commodity Story. Morgan Stanley/Smith Barney.

10. Kucera, J. 2014. Desalination: water from water. John Wiley \& Sons.
11. Matthews, S. 2009. Desalination in Middle East set to grow. Home/Utilities Middle East, 5.

12. Modi, K.V., Modi, J.G. 2019. Performance of single-slope double-basin solar stills with small pile of wick materials. Applied Thermal Engineering, 149, 723-730.

13. Muftah, A.F., Alghoul, M.A., Fudholi, A., AbdulMajeed, M.M., Sopian, K. 2014. Factors affecting basin type solar still productivity: A detailed review. Renewable and Sustainable Energy Reviews, 32, 430-447.

14. Nafey, A.S., Abdelkader, M., Abdelmotalip, A., Mabrouk, A.A. 2000. Parameters affecting solar still productivity. Energy Conversion and Management, 41(16), 1797-1809.

15. Tiwari, A.K., Tiwari, G.N. 2006. Effect of water depths on heat and mass transfer in a passive solar still: in summer climatic condition. Desalination, 195(1), 78-94.

16. Tiwari, G.N., Tiwari, A.K. 2008. Solar distillation practice for water desalination systems. Anshan Pub.

17.Xiao, G., Wang, X., Ni, M., Wang, F., Zhu, W., Luo, Z., Cen, K. 2013. A review on solar stills for brine desalination. Applied Energy, 103, $642-652$. 